\title{
A study on prevalence of anemia and growth pattern among HIV infected children and adolescents from rural areas attending VCTC and ART center Govt. General Hospital, Vijayawada, A.P., India
}

\author{
Baratha Jyothi Naladi, Sunita Kanikaram*
}

From 2nd International Science Symposium on HIV and Infectious Diseases (HIV SCIENCE 2014)

Chennai, India. 30 January - 1 February 2014

\section{Background}

Globally, the HIV epidemic remains a serious challenge, and continues to take its toll particularly on vulnerable populations such as children and adolescents. However, background co-morbidities compound the problem in affected populations in India. Two such major comorbidities include anemia and poor nutrition.

\section{Methods}

The present article deals with the profile of HIV infected children and adolescents in HAART era and Pre-HAART era who were attending the ART centre, Govt. General Hospital, Vijayawada.

\section{Results}

Totally 125 subjects of age group 1-20 years were included in the study. Among $125 \mathrm{HIV}+$ subjects only 45 subjects were in HAARTera, 75 subjects in preHAART era and 5 subjects died during the study period. The study patients in HAART era showed a significant increase $(p<0.001)$ in CD4 counts from 174 to 902 cells/ $\mathrm{cmm}$, significant decrease $(p<0.001)$ in $\mathrm{Hb}$ content from 7.3 to $6.5 \mathrm{gm} / \mathrm{dL}$ and significant increase $(p<0.05)$ in BMI level from 18.1 to 22.6 from baseline to follow up treatment after 18 months. The study patients in preHAART era showed a significant increase $(p<0.05)$ in mean CD4 counts from 592 to 790 cells $/ \mathrm{cmm}$ from

\footnotetext{
* Correspondence: drsunitamichael@gmail.com Department of Zoology and Aquaculture, Acharya Nagarjuna University, Nagarjunanagar, Guntur, Andhra Pradesh, India
}

initial count to count after 18 months. The subjects in preHAART era showed low level of $\mathrm{Hb}$ content $6.9 \mathrm{gm} / \mathrm{dL}$ in male and $6.3 \mathrm{gm} / \mathrm{dL}$ in female subjects; the mean BMI level was 20.43 in male and 18.47 in female subjects.

\section{Conclusion}

Our study reinforces the finding that anemia, growth failure and malnutrition are major manifestations of HIV infection in Indian children with prognostic significance.

Published: 27 May 2014

doi:10.1186/1471-2334-14-S3-P55

Cite this article as: Naladi and Kanikaram: A study on prevalence of anemia and growth pattern among HIV infected children and adolescents from rural areas attending VCTC and ART center Govt. General Hospital, Vijayawada, A.P., India. BMC Infectious Diseases 2014 14(Suppl 3):P55.

Submit your next manuscript to BioMed Central and take full advantage of:

- Convenient online submission

- Thorough peer review

- No space constraints or color figure charges

- Immediate publication on acceptance

- Inclusion in PubMed, CAS, Scopus and Google Scholar

- Research which is freely available for redistribution

Submit your manuscript at www.biomedcentral.com/submit
() Biomed Central 